\title{
TRADISI BANTAI ADAT: KEARIFAN LOKAL MENYAMBUT BULAN RAMADHAN MASYARAKAT MERANGIN JAMBI
}

\author{
BANTAI ADAT TRADITION: LOCAL WISDOM \\ WELCOMING THE MONTH OF RAMADAN, JAMBI'S \\ MERANGIN COMMUNITY
}

\author{
Muhammad Dwi Kurniadi ${ }^{1}$ dan Husmayani Muny Putri ${ }^{2}$ \\ ${ }^{1.2}$ Universitas Negeri Yogyakarta, Indonesia \\ muhammaddwikurniadi@gmail.com
}

DOI: 10.31291/jlka.v19.i2.961

Diterima: 15 September 2021; Direvisi: 15 Desember 2021;

Diterbitkan: 31 Desember 2021

\begin{abstract}
This article aims to describe the bantai adat tradition as local wisdom to welcome the month of Ramadan for the Merangin Jambi community. A qualitative method with an ethnographic approach is used to study, understand and analyze the phenomenon of the people of Merangin Regency, especially in the bantai adat tradition related to religion. This article was written objectively from the results of participant observations, interviews and literature studies conducted in the Merangin Community. Traditional slaughter is a tradition of slaughtering livestock such as cows and buffalo which aims to welcome the month of Ramadan and is carried out a few days before the month of Ramadan. The values contained in the bantai adat tradition include social values, religious values and local cultural values. By getting to know the traditional slaughtering tradition of the Merangin people, it can make the public know about the traditions that exist in Jambi Province.
\end{abstract}

Keywords: Bantai Adat, Merangin, Tradition, Local Wisdom.

\section{ABSTRAK}

Artikel ini bertujuan untuk mendeskripsikan tradisi bantai adat sebagai 
kearifan lokal menyambut bulan Ramadhan bagi masyarakat Merangin Jambi. Metode kualitatif dengan pendekatan etnografi digunakan untuk mempelajari, memahami serta menganalisis fenomena masyarakat Kabupaten Merangin khususnya dalam tradisi bantai adat yang berhubungan dengan keagamaan. Artikel ini ditulis secara objektif dari hasil observasi partisipan, wawancara dan studi literatur yang dilakukan pada Masyarakat Merangin. Bantai adat merupakan tradisi penyembelihan hewan ternak seperti sapi dan kerbau yang bertujuan untuk menyambut datangnya bulan Ramadhan dan dilaksanakan beberapa hari sebelum bulan Ramadhan. Nilai-nilai yang terdapat dalam tradisi bantai adat antara lain nilai sosial, nilai religius serta nilai budaya lokal. Dengan dikenalnya tradisi bantai adat masyarakat Merangin, dapat membuat khalayak ramai mengetahui tentang tradisi yang ada di Provinsi Jambi.

Kata kunci: Bantai Adat, Merangin, Tradisi, Kearifan Lokal.

\section{PENDAHULUAN}

Bantai adat merupakan salah satu tradisi yang terdapat pada Kabupaten Merangin Provinsi Jambi. Kabupaten Merangin merupakan salah satu Kabupaten dari sebelas Kabupaten/Kota di Provinsi Jambi. Kabupaten Merangin terbentuk berdasarkan Undang-Undang Republik Indonesia No. 54 Tahun 1999 tanggal 04 Oktober 1999 tentang pembentukan Kabupaten Sarolangun, Kabupaten Tebo, Kabupaten Muaro Jambi dan Kabupaten Tanjung Jabung Timur. Merangin terbentuk dari pemekaran Kabupaten Sarolangun Bangko menjadi wilayah Kabupaten Merangin dan Kabupaten Sarolangun. Dalam hal ini Kabupaten Merangin sebagai Kabupaten induk tetap dengan ibukota pemerintahan di Kota Bangko, yang dulunya juga merupakan ibukota Kabupaten Sarolangun Bangko sebelum dimekarkan. ${ }^{1}$

Kabupaten Merangin memiliki luas wilayah $7.679 \mathrm{~km}^{2}$ atau 745,130 ha yang terdiri dari $4.607 \mathrm{~km}^{2}$ berupa dataran rendah dan $3.027 \mathrm{~km}^{2}$ berupa dataran tinggi, dengan ketinggian berkisar 46 - $1.206 \mathrm{~m}$ dari permukaan air laut dengan batas wilayah meliputi, sebelah timur: Kabupaten Sarolangun, sebelah barat: Kabupaten Kerinci, sebelah utara: Kabupaten Bungo dan

${ }^{1}$ Redaksi, “Gambaran Umum Kabupaten Merangin”. www. Meranginkab. go.id, 2017, https://Meranginkab.Go.Id/Profile/Gambaran-Umum. 
Kabupaten Tebo serta sebelah selatan: Kabupaten Rejang Lebong (Provinsi bengkulu). Kondisi topografis wilayah Kabupaten Merangin secara umum dibagi dalam 3 (tiga) bagian, yaitu: dataran rendah, dataran sedang, dan dataran tinggi. Pada dataran rendah terletak pada ketinggian 0-100 mdpl dengan luasan $42,77 \%$ luas kabupaten. Wilayah dataran sedang yang terletak antara 100-500 mdpl seluas 32,52\% luas kabupaten. Sedangkan dataran tinggi yang terletak lebih dari 500 mdpl seluas 14,5\% dari luas kabupaten meliputi Kecamatan Jangkat, Muara Siau, Lembah Masurai, Sungai Manau dan sebagian Tabir Ulu. Dataran rendah meliputi Kecamatan Bangko, Pamenang, Tabir, Tabir Selatan dan sebagian Tabir Ulu. ${ }^{2}$

Kabupaten Merangin Jambi merupakan salah satu kabupaten yang memiliki keragaman tradisi yang menjadikannya sebagai salah satu wilayah dengan ciri khas tertentu disbandingkan wilayah lainnya diprovinsi jambi. Tercatat terdapat beragam tradisi seperti tradisi pampeh luko (upacara yang dimaksudkan sebagai tolak balak sekaligus doa selamat bagi kesembuhan luka) di Kec. Muara Siau ${ }^{3}$, tradisi adat makan jantung kerbau di Desa Muara Panco Kec. Renah Pembarap ${ }^{4}$, tradisi naik alang rumah untuk pembangunan rumah di Kec. Pamenang ${ }^{5}$, dan tradisi adat Mukodumah (melakukan do'a dan makan bersama di aula yang telah disediakan) di Desa Renah Alai Kec. Jangkat. ${ }^{6}$ Selain

${ }^{2}$ Ibid.

3 Ahmad Roni, "Makna Filosofis Tradisi Pampeh Luko (Studi di Kecamatan Muara Siau Kabupaten Merangin Provinsi Jambi)", (Universitas Islam Negeri Sulthan Thaha Saifuddin Jambi, 2021), 2.

${ }^{4}$ Madri, "Tradisi Adat Makan Jantung Kerbau Di Marga Tanah Renah Desa Muara Panco Kecamatan Renah Pembarap Kabupaten Merangin Provinsi Jambi (Studi Fenomenologi Edmund Husserl)", (Universitas Islam Negeri Sulthan Thaha Saifuddin Jambi, 2021), 4.

5 Samratul Pigria, "Peran Da'i dalam Menyikapi Tradisi Naik Alang Rumah (Studi di Kelurahan Pamenang Kecamatan Pamenang Kabupaten Merangin)", (Universitas Islam Negeri Sulthan Thaha Saifuddin Jambi, 2019), 48 .

6 Migoni, Saputra, "Tradisi Adat Mukodumah di Desa Renah Alai Kecamatan Jangkat Kabupaten Merangin Provinsi Jambi”, (Universitas Islam Negeri Sulthan Thaha Saifuddin Jambi, 2021), 4. 
tradisi-tradisi tersebut, terdapat tradisi yang hampir dilakukan pada semua tempat di Kabupaten Merangin, tradisi bantai adat atau bebantai atau memantai namanya. Bantai adat ini adalah tradisi penyembelihan sapi atau kerbau untuk menyambut datangnya bulan Ramadhan.

Bulan Ramadan merupakan salah satu barometer keberagamaan umat Islam. Terdapat berbagai ritual yang dilakukan karena diyakini akan mendapat balasan Tuhan yang berlipat ganda. Selama bulan Ramadhan, umat islam wajib melaksanakan puasa, yang berarti harus menahan diri dari segala perbuatan yang dapat membatalkannya sejak terbit fajar hingga terbenam matahari. Selain itu, bulan Ramadhan juga merupakan sarana untuk meningkatkan ketakwaan, sarana berbagi pada sesama umat, sarana pengabdian kepada masyarakat hingga mewujudkan solidaritas sesama makhluk Tuhan. Sejarah puasa Ramadhan pertama kali dimulai pada 10 Sya'ban tahun kedua hijriah atau setengah tahun setelah peristiwa hijrah dari Mekkah ke Madinah. Rasulullah shallallahu 'alaihi wa sallam sempat melaksanakannya selama sembilan tahun sebelum beliau wafat pada bulan Rabi'ul Awwal tahun ke-11 hijriyah (Al-Fiqh al-Islami wa Adillatuhu (2/578), Fih as-Sunnah (1/433)). ${ }^{7}$

Ramadhan sendiri berasal dari akar kata bahasa Arab yaitu ramidha atau arramadh yang berarti panas yang terik dan kering. Dari akar yang sama juga ada ramadhaa, yang memiliki arti pasir yang terjemur. Dengan demikian Ramadhan adalah metafora untuk menunjukkan sebuah sensasi panas yang mendidihkan perut akibat lapar dan dahaga. Begitu pula ahli balaghah arab menyatakan bahwa dinamakan Ramadhan karena begitu menyengat panasnya di bulan itu, hingga bayi pun merasa kepanasan (Tafsir Ath Thabari, 3/44). ${ }^{8}$

Ibnu Mandzur (630-711 H) seorang ahli bahasa Arab menjelaskan bahwa Ramadhan berasal dari kata al-ramadh yang artinya panas batu akibat sengatan matahari. Ada pula yang mengatakan bahwa Ramadhan berasal dari akar kata ramidha

7 Naser Muhammad, Menggapai Mulia Ramadhan dengan Ilmu. (Lampung: Perahu Litera, 2018), 41-42.

${ }^{8}$ Ibid., 42-44. 
yang berarti keringnya mulut orang yang berpuasa akibat haus dan dahaga. Berdasarkan pandangan bahasa tersebut, Ramadhan menjadi simbol sengatan matahari yang bisa memengaruhi dan memanaskan batu. Batu sering menjadi simbol Al-Qur'an saat menyorot kerasnya hati manusia, atau disebut hati batu. Sekalipun hati seseorang keras seperti batu, Ramadhan sanggup membuatnya panas dan terpengaruh jika orang tersebut mau menerima ajaran selama bulan Ramadhan. ${ }^{9}$

Al-Khalil berpendapat bahwa kata Ramadhan berasal dari kata ramdha yang artinya batu. Ramadhan al-insan, maknanya manusia berjalan di atas jalan bebatuan. Ramadhan disebut demikian karena di bulan itu dosa akan dihancurkan. Pendapat lain mengatakan bahwa Ramadhan disebut demikian karena ia merupakan bulan penyucian tubuh dan penyucian hati. Kata ini diambil dari kata ramadh yang artinya hujan yang datang sebelum musim gugur. Kata ramadha pada Ramadhan dikatakan pula memiliki satu makna dengan kata rafadha, yang bermakna menolak. Hal ini dikarenakan pada bulan itu, ada satu kaum yang menolak mendekatkan diri pada Tuhannya, sementara kaum lainnya menolak menuju tempat yang dimurkai Tuhannya. ${ }^{10}$

Bulan Ramadhan umumnya dikenal pula sebagai bulan puasa. Puasa merupakan aktivitas pemberhentian konsumsi makan dan minum ketika siang hari di mulai dari terbit fajar hingga terbenam matahari. Kegiatan yang dilakukan untuk melatih hawa nafsu dengan menahan motif konsumsi dan hubungan seksual. Hasil dari latihan berpuasa akan melahirkan sifat kesederhanaan dalam konsumsi, memunculkan sifat-sifat spritual yang terpuji seperti kesabaran, rasa syukur, qona ‘ah dan sifat yang terpuji lainnya. Sehingga ibadah puasa yang dilakukan dapat membentuk kepribadian beriman dan bertaqwa. ${ }^{11}$ 2007), 3.

${ }^{9}$ Yusuf Burhanudin, Misteri Bulan Ramadhan. (Jakarta: Qultummedia,

10 Ibnu Jauzi. Diterjemahkan oleh Iman Firdaus, Suluh Penyucian Jiwa. (Jakarta: Qisthi Press, 2016), 322.

11 Habriyanto, Muhammad Yasir Nasution and Muhammad Yusuf Harahap, "Analisis Pola Konsumsi Masyarakat Kota Jambi pada Bulan 
Memaknai Ramadhan berkaitan dengan gerak hati dan pikiran. Ramadhan selama tiga puluh hari dapat mengubah visi, misi dan arah fikiran seseorang. Melalui puasa di siang hari dan shalat tarawih di malam hari, I'tikaf disepertiga akhirnya serta membayar zakat merupakan cara-cara untuk menuai kesucian di bulan Ramadhan. Selain itu, dengan adanya Ramadhan, artinya memberi makan rohani orang yang menjalankannya. Sebagaimana tubuh, hatipun ternyata perlu diberi makanan.

Bulan Ramadhan merupakan arena pergulatan penting guna membina kualitas pribadi seseorang melalui berbagai pendidikan rohani. Ragam ritual dan ketulusan spiritual diselenggarakan sebagai bekal menyongsong "peperangan" sebenarnya dalam hidup di sebelas bulan berikutnya. Dari awal hingga akhir bulan Ramadhan adalah saat-saat menempa berbagai pelatihan untuk mendewasakan hati, pikiran, serta sikap selama ini. Ramadhan menjadi bulan suci dan penuh berkah bagi umat islan karena terdapat enam keutamaan yaitu bulan diturunkannya AlQur'an, puasa di siang hari, shalat tarawih di malam hari, malam lailatul qadr, pelaksanaan zakat fitrah dan hari raya idul fitri. ${ }^{12}$

Bulan Ramadhan adalah bulan di mana para budak diringankan bebannya, lentera dinyalakan berwarna-warni, bulan turunnya rahmat yang dibawa oleh Jibril a.s., dibacakan AlQur'an, dan bulan para musafir diberi keringanan. Bulan Ramadhan di dunia seperti halnya surga di Hari Akhir, kerajaannya abadi, berkesinambungan dan tidak musnah. Oleh karena itu, sambutlah Ramadhan dengan suka cita karena bulan Ramadhan adalah bulan di mana keburukan dan cela ditutupi, jiwa dan hati menjadi lembut serta dosa dan kesalahan diampuni. ${ }^{13}$

Banyak cara yang dilakukan untuk memaknai Ramadhan, salah satunya yang menarik adalah adanya keunikan kearifan lokal yang dilakukan masyarakat pada tiap tempat yang berbeda

Ramadhan Menggunakan Pendekatan Smart Pls 3.0", Jurnal Ilmiah Universitas Batanghari 19, no. 1 (2019), 118. DOI: 10.33087/Jiubj.V19i1.573

12 Burhanudin, Op. Cit., 11-12.

13 Jauzi, Op. Cit., 322-323. 
antara satu dengan yang lainnya. Kearifan lokal tersebut dapat berupa tradisi, petatah-petitih, dan lain sebagainya. Salah satu kearifan lokal yang akrab dengan keseharian masyarakat adalah tradisi. Tradisi umumnya berupa kebiasaan yang telah dilakukan secara turun menurun dari satu generasi ke generasi berikutnya yang didalamnya terdapat nilai-nilai kebaikan. Melalui tradisi, tidak hanya melestarikan warisan leluhur, namun juga menjadi sarana silaturahmi dan mempererat persaudaran antar masyarakat dalam wilayah tertentu.

Contoh Tradisi tersebut antara lain tradisi padusan atau mandi disuatu empang atau kolam atau pemandian umum pada bulan Sya'ban (ruwah) dalam menyambut bulan suci Ramadhan yang dilakukan masyarakat Jawa Tengah dan Yogyakarta ${ }^{14}$, Balimau Kasai yaitu tradisi mandi beramai-ramai menyambut bulan suci yang biasanya dilakukan sehari sebelum puasa oleh masyarakat Kampar di Riau ${ }^{15}$, tradisi ziarah kubur masyarakat Seberang Kota Jambi yang dilakukan pada hari-hari mendekati bulan Ramadhan dan hari raya Idul Fitri kedua secara beramairamai oleh satu desa dan kelurahan sesuai waktu yang telah disepakati bersama ${ }^{16}$, serta tradisi bantai adat (menyembelih sapi dan kerbau) bagi masyarakat Merangin Jambi dan lain sebagainya.

Kearifan lokal dapat didefinisikan sebagai kebijaksanaan atau nilai-nilai luhur yang terkandung dalam kekayaan-kekayaan budaya lokal, berupa tradisi, petatah-petitih, dan semboyan hidup. Kearifan lokal (local wisdom) dapat dipahami sebagai gagasan, nilai-nilai, pandangan-pandangan setempat yang bersifat bijaksana, penuh kearifan, bernilai baik, yang tertanam dan diikuti oleh anggota masyarakatnya. Kearifan lokal yang terdapat pada beberapa kelompok/ masyarakat adat di Indonesia banyak

${ }^{14}$ Abu Maryam Kautsar Amru, Memantaskan Diri Menyambut Ramadhan. (Ciputat: Kautsar Amru Publishing, 2018), 64.

15 Fitri Haryani Nasution, 70 Tradisi Unik Suku Bangsa di Indonesia. (Jakarta: Bhuana Ilmu Populer, 2019), 21.

${ }^{16}$ Ari Yuda Kusuma and Aman, "Budaya Keagamaan Arab Melayu Seberang Kota Jambi”, Jurnal Lektur Keagamaan 19, no. 1 (2021), 256. DOI: 10.31291/jlk.v19i1.899 
mengandung nilai luhur budaya bangsa yang masih kuat menjadi identitas karakter warga masyarakatnya. ${ }^{17}$

Kearifan lokal yang tercermin dalam kebiasaan hidup masyarakat yang telah berlangsung lama dalam perkembangannya dapat berubah wujud menjadi tradisi, meskipun prosesnya membutuhkan waktu yang sangat panjang. Suatu kebiasaan yang turun temurun dalam sebuah masyarakat dengan sifatnya yang luas disebut dengan tradisi, yang meliputi segala kompleks kehidupan, sehingga tidak mudah disisihkan dengan perincian yang tepat dan pasti, terutama sulit diperlakukan serupa atau mirip, karena tradisi bukan objek yang mati, melainkan alat yang hidup untuk melayani manusia yang hidup pula. ${ }^{18}$

Indonesia merupakan Negara yang memiliki keragaman budaya, suku, ras, adat-istiadat, serta tradisi yang berbeda-beda diantara satu tempat dengan tempat lainnya. Perbedaan diantara tempat tersebut nyatanya malah menawarkan keunikan dan keindahan yang menjadi ciri bangsa Indonesia dimata dunia. Sejalan dengan itu, berkembangnya ilmu pengetahuan dan teknologi dikhawatirkan akan mengurangi makna dan menggerus kesakralan tradisi yang dimiliki oleh masyarakat adat. Dengan demikian, perlu adanya pelestarian terkait tradisi adat setempat agar tradisi tersebut tetap ada dan terjaga hingga masa mendatang.

Tradisi dalam Bahasa Latin yaitu tradition yang berarti diteruskan atau kebiasaan. Dalam pengertian yang paling sederhana, tradisi adalah sesuatu yang telah dilakukan sejak lama dan menjadi bagian dari bagian suatu kelompok masyarakat, biasanya dari suatu Negara, kebudayaan, waktu atau pemahaman yang sama. Hal yang paling mendasar dari tradisi adalah adanya informasi yang diteruskan dari generasi ke generasi baik lisan maupun tulisan. Dengan kata lain, tradisi dapat pula diartikan sebagai kebiasaan yang turun temurun dalam masyarakat yang

17 Muhammad Priyatna, "Pendidikan Karakter Berbasis Kearifan Lokal", Jurnal Edukasi Islami Jurnal Pendidikan Islam 5, no. 10 (2016), 1313. http://dx.doi.org/10.30868/ei.v5i10.6

${ }^{18}$ Amalia Pintenate and Bukhari, "Pacuan Kuda dalam Kajian Sosiologi (Suatu Penelitian di Kabupaten Bener Meriah)", Jurnal Ilmiah Mahasiswa FISIP Unsyiah 2, no. 2 (2017), 911. 
merupakan kesadaran kolektif masyarakat, hasil karya masyarakat, yang merupakan personafikasi sebuah makna hukum tidak tertulis yang menjadi patokan norma dalam masyarakat dan dianggap benar. ${ }^{19}$

Keragaman tradisi yang ada di Indonesia sudah sepatutnya dilestarikan dan dijaga agar tradisi yang ada di suatu tempat tersebut tidak kehilangan jati diri dan dapat dilaksanakan atau diteruskan pada generasi-genarasi di masa mendatang. Berkaitan dengan tradisi dan bulan Ramadhan, terdapat salah satu tradisi unik yang terdapat di Kabupaten Merangin Jambi. Bantai adat, atau bebantai atau memantai menjadi salah satu tradisi yang hingga kini masih dilakukan oleh masyarakat sekitar dan menjadi salah satu ciri tempat tersebut saat menyambut bulan Ramadhan. Pengetahuan tentang tradisi ini penting untuk disebarluaskan sebagai sarana pendukung literasi budaya khususnya di kalangan generasi muda agar mengetahui apa saja tradisi yang ada di Indonesia baik tradisi yang ada di daerah setempat, ataupun tradisi yang terdapat diluar daerahnya.

Metode yang digunakan dalam artikel ini adalah metode kualitatif dengan pendekatan etnografi untuk mempelajari, memahami serta menganalisis fenomena masyarakat Kabupaten Merangin khususnya dalam tradisi yang berhubungan dengan keagamaan. Artikel ini ditulis secara objektif dari hasil observasi partisipan, wawancara dan studi literatur yang dilakukan kepada masyarakat Merangin. Penggunaan metode ini didasarkan pertimbangan bahwa kajian ini mengarah pada fenomena sosiokultural yang bersifat deskriptif. Etnografi pada dasarnya merupakan kajian yang terkait dengan antropologi, mempelajari peristiwa kultural yang menyajikan pandangan hidup subyek yang menjadi objek penelitian ${ }^{20}$. Bagi etnografer, temuan kajian

19 Fransiska Idaroyani Neonnub and Novi Triana Habsari, "Belis: Tradisi Perkawinan Masyarakat Insana Kabupaten Timor Tengah Utara (Kajian Historis Dan Budaya Tahun 2000-2017)", Jurnal Agastya 08, no. 01 (2018), 109. http://doi.org/10.25273/ajsp.v8i01.2035

${ }^{20}$ Mohammad Siddiq and Hartini Salama, "Etnografi Sebagai Teori Dan Metode", Kordinat Xviii, no. 1 (2019), 25. DOI: 10.15408/kordinat. v18i1.11471 
tidak dapat dipisahkan dari lokasi tertentu (spesifik) dan lingkungan di mana data kajian dikumpulkan. Sebuah studi menjadi etnografi ketika peneliti lapangan menghubungkan fakta dengan latar belakang yang mendasari fakta yang terjadi terutama dalam kaitannya dengan kontintensi sejarah serta budaya $^{21}$. Melalui metode etnografi pula peneliti hendak menggambarkan, menganalisis, dan menafsirkan budaya kelompok dari waktu ke waktu untuk memahami sikap, keyakinan, konsep, perilaku, dan bahasa yang menjadi milik bersama kelompok tersebut. Sejalan dengan pendapat tersebut peneliti berusaha mengetahui bagaimana anggota-anggota komunitas mendefinisikan norma (norms), kebudayaan (culture), adat istiadat (mores), dan nilai (values). ${ }^{22}$

\section{HASIL DAN PEMBAHASAN}

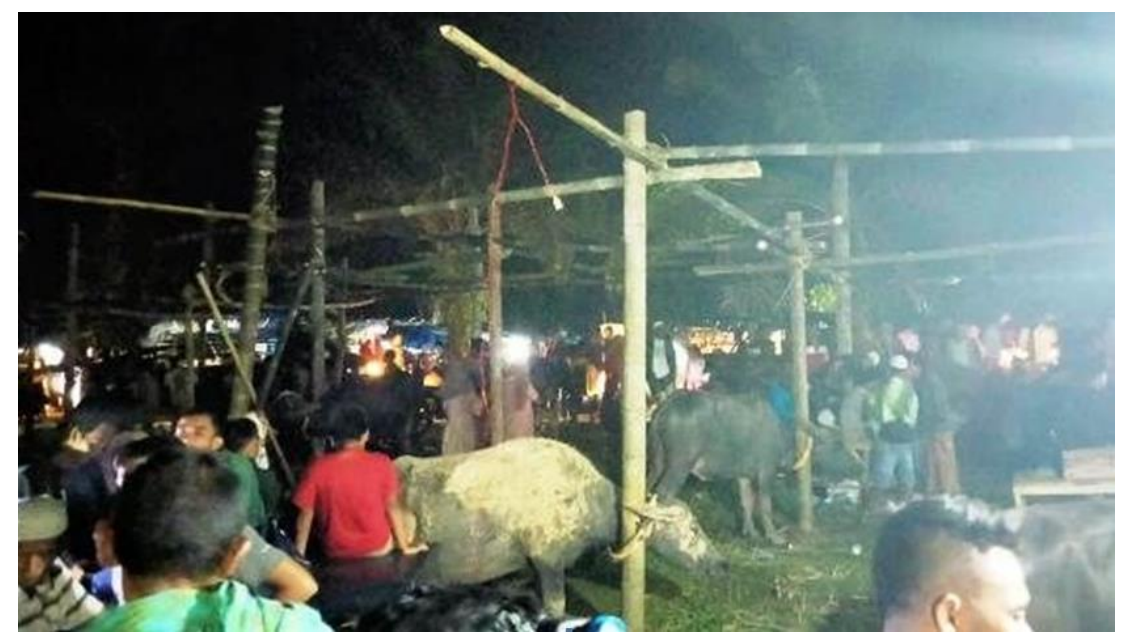

Sumber: jambiberita.com, 2021

\section{Gambar 1.}

21 Windiani and Farida Nurul Rahmawati, "Menggunakan Metode Etnografi dalam Penelitian Sosial", Dimensi 9, no. 2 (2016), 88.

22 Umar Suryadi Bakry, "Pemanfaatan Metode Etnografi dan Netnografi Dalam Penelitian Hubungan Internasional”. Global \& Strategis 11, no. 1 (2017), 19. http://dx.doi.org/10.20473/jgs.11.1.2017.15-26 
Hewan yang Dikumpulkan untuk Tradisi Bantai Adat

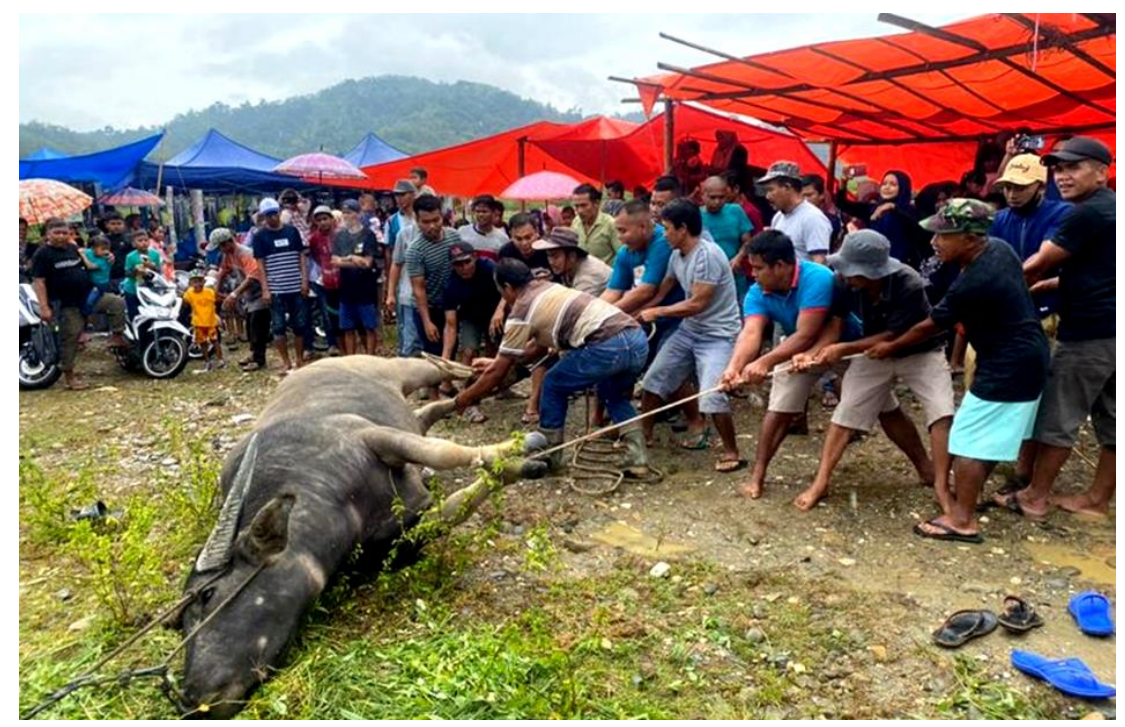

Sumber: Suwandi, 2021

\section{Gambar 2.}

Tradisi Bantai Adat di Kecamatan Pangkalan Jambu dalam Menyambut Bulan Suci Ramadhan, Sabtu (10/4/2021)

\section{Sejarah Bantai Adat Merangin Jambi}

Berdasarkan keterangan peneliti sejarah Balai Pelestarian Nilai Budaya (BPNB) Kementerian Pendidikan dan Kebudayaan, Dedi Arman, tentang Sejarah Bantai Adat dalam wawancara pada harian online Kompas, menjelaskan bahwa bantai adat berasal dari kisah Datuk Putih dan Datuk Mangkuto Rajo. Pada mulanya, Datuk Putih dan Datuk Mangkuto Rajo menemukan sebuah tempat yang disebut dengan nama Renah Sungai Kunyit, sekarang dinamakan Kecamatan Pangkalan Jambu. Dahulu dinamakan Renah Sungai Kunyit karena saat ditemukan oleh kedua Datuk tersebut banyak terdapat bijih emas. Saat itu, Pangkalan Jambu masih ditutupi hutan yang lebat dan termasuk 
wilayah kekuasaan Depati Muara Langkap yang berkedudukan di Tamiai (Kerinci). ${ }^{23}$

Kedua Datuk tersebut akhirnya membuat gelanggang tempat menyabung ayam di Renah Sungai Kunyit yang sekarang disebut Kecamatan Pangkalan Jambu untuk meramaikan Renah Sungai Kunyit. Akhirnya gelanggang pun semakin ramai. Untuk mencari modal menyabung ayam, orang-orang yang datang dari berbagai penjuru negeri menambang emas dan bertani. Sehingga banyak pendatang baru yang menetap disana dan membuat rumah serta mengolah sawah. Ramainya kedatangan para pendatang yang memiliki perbedaan adat-istiadat, menjadikan perlu dibuatnya undang-undang untuk mengatur masyarakat Renah Sungai Kunyit. Untuk menemukan undang-undang yang cocok, maka Datuk Putih dan Datuk Mangkuto Rajo bersama utusan Depati Muara Langkap melakukan sidang

Setelah melakukan sidang, lalu diputuskan undang-undang adat Negeri Pangkalan Jambu adalah kombinasi undang-undang yang turun dari Minangkabau dan dari Jambi. Inti dari undangundang ini adalah wajah nan tigo dan pembetulan nan duo. Untuk wajah nan tigo yaitu Buek yang berarti keputusan- keputusan yang disahkan bersama, lalu pakai adalah kewajiban untuk mematuhi dan menjalankan aturan dan ketiga peseko yaitu setiap yang telah menjadi keputusan wajib dipatuhi dan dijalankan sampai turun temurun. Kemudian pembetulan nan duo adalah, perbetulan Syarak dan perbetulan Adat.

Agar undang-undang tersebut kekal, kedua datuk tersebut mengundang semua tokoh di Renah Sungai Kunyit dan meresmikan hukum adat tersebut pada hari di akhir bulan Sya'ban di Pondok Pekan Puaso yang dipilih sebagai hari baik. Tokoh-tokoh tersebut antaralain Depati Muaro Langkap di Tamiai, Depati Atur Bumi di Hiang, Depati Setio Rajo di Lubuk Gaung, Depati Rencong Telang di Pulau Sangka, Depati Setio Nyato di Tanah renah, Depati Setio Beti (Bakti) di Nalo Tantan dan Depati Biang

${ }^{23}$ Suwandi, "Mengenal Sejarah Bebantai, Tradisi Sambut Ramadhan di Merangin", Kompas Online, 2021, https://regional.kompas.com/read/2021/ 04/13/184345578/mengenal-sejarah-bebantai-tradisi-sambut-ramadhan-dimerangin?page $=$ all. 
Sari di Pangasi. Selain itu juga diundang negeri Luhak XVI Ma. Siau/Pamuncak Koto Tapus-Serampas, Siangit Sungai Tabir, Limun Batang Asai dan Daerah Uluan Palembang.

Pada jamuan besar tersebut, Datuk Putih dan Datuk Mangkuto Rajo memotong kerbau sebanyak 48 ekor. Kegiatan tersebut tetap terlaksana sampai sekarang dan menjadi tradisi yang dinamakan bantai adat. Hingga sekarang, daerah di Merangin khususnya Kecamatan Pangkalan Jambu, Sungai Manau, Batangasai dan Rantau Panjang masih melaksanakan tradisi bebantai tersebut.

\section{Pelaksanaan Tradisi Bantai Adat Merangin Jambi}

Masyarakat Merangin mayoritas beragama Islam. Saat bulan Ramadhan datang, mereka menyambutnya dengan penuh suka cita. Di jalan banyak penjual kurma, kembang api, perlengkapan ibadah yang menambah semarak khas suasana Ramadhan yang hanya dapat dirasakan satu tahun sekali. Datangnya Ramadhan disambut dengan berbagai kegiatan oleh masyarakat seperti membersihkan sarana umum, melaksanakan pengajian dan melaksanakan tradisi yang unik yaitu bebantai, memantai, atau lebih dikenal dengan bantai adat.

Bebantai dalam bahasa Indonesia berarti membantai. Bantai adat dimaknai sebagai kegiatan memotong hewan seperti sapi dan kerbau dalam rangka menyambut datangnya bulan Ramadhan. Hampir seluruh desa tradisional di Merangin menyelenggarakan bantai adat ini. Kegiatannya dilaksanakan selama tiga hingga lima hari sebelum masuknya bulan Ramadhan. Tujuannya adalah melestarikan tradisi dan memenuhi kebutuhan daging masyarakat walaupun sebenarnya kebutuhan masyarakat tidaklah sama. Namun pada tradisi bantai adat ini, semua masyarakat baik suka dan yang tidak suka akan ikut serta. ${ }^{24}$

Bantai adat adalah pelestarian kegiatan adat dalam menyambut bulan puasa. Lembaga adat mengharapkan masyarakat bergembira menyambut bulan Ramadhan dengan ibadah pemo-

${ }^{24}$ Alhusni, "Tradisi Bebantai Menyambut Bulan Ramadan dalam Masyarakat Merangin Jambi”, Kontekstualita 29, no. 1 (2014), 45. 
tongan massal sapi dan kerbau. Dagingnya bisa dijual lebih murah dari harga pasar. Tradisi bantai adat merupakan salah satu bentuk kegiatan untuk memperoleh gambaran tentang keterlibatan lembaga adat dalam menampung dan menyalurkan aspirasi masyarakat yang dapat menjadi acuan pembangunan berbagai fasilitasi yang dihasilkan dari realisasi aspirasi masyarakat. Keterlibatan lembaga adat mendorong masyarakat untuk berpartisipasi dalam perencanaan pembangunan dalam hal-hal seperti menampung aspirasi masyarakat dan menyalurkannya ke kewenangan tingkat kecamatan. Pembangunan arena kegiatan bantai adat ini dilakukan tiga hari sebelum puasa dengan dana dari pemerintah kabupaten. Tahap pembangunan dilakukan oleh penyandang dana dari pemerintah kabupaten setempat sebagai hasil dari musrembang yang diusulkan secara gotong royong. ${ }^{25}$

Hewan yang disembelih pada bantai adat merupakan hasil pembelian dari beberapa kepala keluarga dan dagingnya dibagikan kepada keluarga yang membeli hewan itu. Selain itu, ada juga hewan yang tidak dibeli secara kelompok. Melainkan dibeli dan disembelih oleh para pedagang. Dagingnya kemudian dijual kepada masyarakat dengan harga dibawah harga pasar. Biasanya daging yang didapat dari tradisi ini, masing-masing akan dimasak oleh keluarga untuk kebutuhan selama Ramadhan. Selain itu, tradisi ini juga mampu menekan harga daging di pasaran sehingga harga daging tidak melambung menjelang Ramadhan. ${ }^{26}$

Tradisi ini merupakan tradisi menyambut bulan Ramadhan yang umumnya telah direncanakan sejak awal tahun melalui rapat oleh anggota masjid atau komunitas tertentu. Setelah tradisi bantai dilakukan, sumber protein hewani dari sapi atau kerbau tersebut lalu digunakan untuk tradisi makan besamo (makan bersama-sama sebagai rasa syukur menyambut Ramadhan dan mempererat silaturahmi). Makan besamo biasanya diikuti berbagai kegiatan keagamaan lain seperti beduon (umumnya ditujukan

${ }^{25}$ Riri Maria Fatriani and Faizah Bafadhal, "Involvement Of Malay Customary Institution In Organizing Development At Tabir Sub-District Merangin Regency", Proceedings of The 1st Progress in Social Science, Humanities and Education Research Symposium (Psshers 2019), 2019, 638.

${ }^{26}$ Asrori, "Warga Merangin Punya Tradisi Bantai Adat", Info Jambi. com, 2017, https://infojambi.com/9472-2/. 
untuk memanjatkan doa pada Allah agar diberi keselamatan, rahmat dan ampunan), dan isthighosah (kegiatan berdzikir untuk mendapat kesehatan dan menghindari bala' selama puasa). ${ }^{27}$

Menurut keterangan Roni pada tahun 2021 dalam wawancaranya dengan Mohd. Isya sebagai pemuka adat desa Pulau Raman Kecamatan Muara Siau Merangin, tradisi bantai adat ini dikenal pula dengan nama Megang atau sering dikenal dengan Bebantai menyambut bulan suci ramadhan. Megang adalah tradisi menyambut bulan ramadhan yang dilaksanakan beberapa hari sebelum masuknya bulan suci Ramadhan. Tujuan dari tradisi megang ini selain melestrasikan tradisi juga untuk memenuhi kebutuhan masyarakat memeriahkan menyambut bulan puasa. ${ }^{28}$

Pada masyarakat Desa Tanjung Mudo Kabupaten Merangin, biasanya tradisi ini disebut dengan bebantai adat yang dilakukan dua hari menjelang bulan puasa. Biasanya pada acara ini, hewan yang disembelih adalah sapi atau kerbau. Daging sapi atau kerbau tersebut lalu dijual kepada warga dengan harga yang relatif murah. Seluruh masyarakat desa umumnya mendapatkan daging tersebut termasuk keluarga yang tidak mampu. Bagi masyarakat Desa Tanjung Mudo, tradisi ini bukan hanya sekedar melaksanakan ibadah puasa namun sarana untuk menjalin silaturahmi, solidaritas serta kebersamaan. ${ }^{29}$

Pada dasarnya, sistem atau cara bantai adat ada tiga jenis. Cara pertama adalah panitia melaksanakan pembantaian lalu dagingnya dijual dengan harga tertentu kepada masyarakat yang telah terdaftar sebagai peserta bantai. Lalu keuntungannya akan digunakan untuk pembangunan Masjid. Cara kedua adalah masyarakat secara iuran membeli sapi atau kerbau dan melakukan bantai adat lalu keuntungannya lalu dibagi rata. Cara ketiga adalah individu atau pemilik ternak sengaja membanta hewannya pada hari bantai dan dijual kepada masyarakat. Tradisi ini

${ }^{27}$ Alhusni, Op. Cit., 46.

${ }^{28}$ Roni, Op.Cit., 37.

${ }^{29}$ Hartati, "Pembacaan Surat-Surat Pilihan Pada Tradisi Selamatan Pindah Rumah di Desa Tanjung Mudo Kecamatan Pangkalan Jambu Kabupaten Merangin Jambi (Studi Living Qur'an)". (Universitas Islam Negeri Sulthan Thaha Saifuddin Jambi, 2021), 35. 
biasanya dilakukan pada tempat tertentu seperti pusat desa atau kecamatan.

Bantai adat selalu ditunggu oleh masyarakat Merangin, bahkan para perantau banyak yang pulang kampung hanya untuk mengikuti tradisi tersebut karena dianggap sangat penting demi menjalin kebersamaan, silaturahmi, serta solidaritas bagi setiap lapisan masyarakat disana. Uniknya lagi, hewan sapi atau kerbau yang dipotong dalam bantai adat ini jumlahnya mencapai ratusan ekor. ${ }^{30}$

Menurut penuturan Akhmad, salah satu warga Kec. Tabir yang diwawancarai oleh liputan6.com pada 2017 mengatakan bahwa biasanya Kec. Tabir merupakan daerah yang paling banyak menyembelih ternak untuk menyambut Ramadhan. Pada tahun 2016, tercatat 120 ekor kerbau 'dibantai' pada tradisi bantai adat ini. Sebelum disembelih, ratusan kerbau dikumpulkan dahulu dan diikat di lokasi lapang. Proses pembantaian biasanya dilakukan pada dini hari antara pukul 03.00 WIB hingga menjelang subuh $^{31}$. Namun demikian menurut keterangan Fuadi, salah satu tokoh masyarakat di Kec. Tabir pada harian online jambiberita.com, bantai adat di tahun 2021 ini sangat dinantikan masyarakat karena sebelumnya sempat terhenti karena wabah covid-19. Pada tahun 2021 ini diketahui bahwa tradisi bantai adat menghabiskan dana berkisar Rp. 1,4 Miliar dengan daging berjumlah 10 ton. Selain itu, tradisi pada tahun 2021 merupakan inisiatif masyarakat setempat, bukan berasal dari panitia karena adanya kejadian aneh yang dipercaya masyarakat setempat. ${ }^{32}$

Hewan yang diikat dan akan disembelih tersebut terikat kuat di sebuah tonggak dari batang pinang ditengahnya. Biasanya pria-pria yang badannya kekar akan menarik tali saat

${ }^{30}$ Saulatiya, "Kebijakan Pemerintah Dalam Pelestarian Rumah Tuo Di Kelurahan Kampung Baruh Kecamatan Tabir Kabupaten Merangin Provinsi Jambi”, (Universitas Islam Negeri Sulthan Thaha Saifuddin Jambi, 2021), 43.

31 Bangun Santoso, "Tradisi Bantai Kerbau Sambut Ramadan di Merangin Jambi”, Liputan 6.com, 2017, https:/www.liputan6.com/ ramadan/ $\mathrm{read} / 2961895 /$ tradisi-bantai-kerbau-sambut-ramadan-di-merangin-jambi.

32 Redaksi, “Adat Mamantai Kerbau Rantau Panjang, Habiskan Rp 1,4 Miliar”, Jambiberita.com, 2021, https://jamberita.com/read/2021/04/10/ 5966942/adat-mamantai-kerbau-rantau-panjang-habiskan-rp-14-miliar/. 
seorang pemuka adat memebri arah. Lalu puluhan lelaki menyerbu, menarik, berteriak dan hewan-hewan tersebut telah siap untuk disembelih. Saat pembantaian ini, dihadari pemuka agama, pemuka adat serta tokoh masyarakat yang berpusat di balai (sebidang tanah kosong di belakang pasar) atau tanah lapang.

Tradisi bantai adat yang dilakukan pada tahun 2018 di Desa Perentak, diketahui menjelang Ramadhan, harga daging kerbau paling tinggi Rp. $75.000 / \mathrm{kg}$ sedangkan harga dipasaran aslinya mencapai Rp. $120.000 / \mathrm{kg}$. Dengan adanya tradisi bantai adat, seluruh warga desa mampu membeli daging kerbau untuk kebutuhannya selama Ramadhan. Uniknya lagi, harga yang relatif murah ini menjadikan warga desa lebih mengutamakan membeli daging kerbau saat tradisi bantai adat dibandingkan membeli baju saat lebaran untuk adu gengsi kemewahan. ${ }^{33}$

Tradisi pembantaian atau sering disebut dengan acara pembantaian adat oleh masyarakat Merangin khususnya Rantau Panjang ini, umumnya diselingi pula dengan tarian Dendang Rumah Tuo. Tari Dendang Rumah Tuo merupakan salah satu bentuk kesenian yang ada di Rantau Panjang Kecamatan Tabir Kabupaten Merangin Provinsi Jambi. Tari Dendang Rumah Tuo terinspirasi dari salah satu aktifitas masyarakat Rantau Panjang yaitu bertani. Setelah mereka selesai panen padi, hasil panen padi tersebut di bawa ke Rumah Tuo selain untuk menyimpan hasil panen padi, Rumah Tuo digunakan oleh masyarakat untuk berkumpul-kumpul untuk membicarakan segala sesuatu yang berhubungan dengan kehidupan, setelah pembicaraan selesai mereka berdendang-dendang sambil bergoyang-goyang karena sangat bahagia dengan hasil panen padi mereka. ${ }^{34}$

${ }^{33}$ Saragih, Radesman, "Tradisi Bantai Adat, Perekat Kebersamaan Memasuki Bulan Ramadan”, Beritasatu.com, 2018, https://www. Beritasatu. com/ramadan/493250/tradisi-bantai-adat-perekat-kebersamaan-memasukibulan-ramadan.

${ }^{34}$ Suci Ramadani, Risnawati and Yarlis, "Tari Dendang Rumah Tuo pada Masyarakat Rantau Panjang Kecamatan Tabir Kab. Merangin Prov. Jambi”, Jurnal Laga-Laga 5, no. 2 (2019). 
Seperti yang telah dijelaskan sebelumnya, tradisi bebantai ini diikuti oleh kegiatan keagamaan lain antaralain seperti makan besamo, beduon dan istighosah.

\section{Makan besamo}

Makan besamo adalah kegiatan berupa makan bersamasama yang dilakukan oleh suatu keluarga dengan memasak daging yang diperoleh dari tradisi bantai adat tersebut. Tuan rumah biasanya akan mengundang keluarga dan koleganya saat makan besamo tersebut. Dalam kegiatan ini, tidak ada ritual khusus dan hanya ditujukan untuk bersuka ria menyambut Ramadhan sebagai tanda syukur berbagi kenikmatan serta mempererat tali persaudaraan.

\section{Beduon}

Beduon, disebut pula bedua atau beduen merupakan kegiatan sosial keagamaan dengan tujuan tertentu. Umumnya kegiatan ini ditujukan untuk memanjatkan doa kepada Allah agar diberi keselamatan, rahmat dan ampunan kesalahan baik bagi individu, keluarga, masyarakat ataupun leluhur. Beduon ini biasanya diadakan pada upaca pernikahan, kelahiran anak, lulus sekolah, naik jabatan, panenan dan pada saat menyambut bulan puasa. Pelaksanaannya dilakukan di rumah masingmasing dengan mengundang masyarakat untuk hadir ke rumah. Beduon yang dilakukan untuk menyambut bulan Ramadhan bertujuan sebagai wujud rasa syukur atas nikmat dan karuna Allah SWT serta mengenang leluhur terdahulu yang memiliki hubungan keluarga dengan penyelenggara. Kegiatan Beduon ini berupa Shalawatan, membaca kalimat toyyibah, ayat Al-Qur'an, Surat Yassin serta doa selamat. Kegiatan ini ditutup dengan makan bersama dengan tuan rumah. $^{35}$

\section{Isthighosah}

Makna istighosah adalah menghadiri suatu majelis untuk melaksanakan ibadah, do'a, dzikir, dan bersholawat bersama

${ }^{35}$ Alhusni, Op. Cit., 46-47. 
yang bermanfaat untuk memohon bantuan, minta pertolongan kepada Allah SWT. Atas segala sesuatu yang dihadapi manusia yang dipimpin oleh orang alim atau orang yang berilmu ${ }^{36}$. Istighosah merupakan salah sau ritual yang biasanya melibatkan lebih banyak orang dan bahkan bersifat kolosal. Hakikat istighosah adalah dzikir bersama, doa bersama dan taubat bersama. Istighosah dimaksudkan untuk semakin mendekatkan diri kepada Allah dan memohon ampunan atas dosa-dosa yang telah dilakukan. Biasanya yang memimpin istighosah bukanlah orang sembarang, namun harus kyai yang sudah dipercaya kealimannya. ${ }^{37}$

Begitupula yang dilakukan oleh masyarakat Merangin, salah satunya Desa Parit Ujung Tanjung, melakukan istighosah menyambut bulan Ramdhan. Tujuannya adalah mendapatkan kesehatan serta menghindari bala' selama menjalankan ibadah puasa. Dalam istighosah ini, dibaca surat Yassin, shalawat, serta doa-doa kepada Allah SWT. Biasanya istighosah dilakukan dua atau tiga hari sebelum bulan Ramadhan yang dikelola oleh tim persatuan majelis silaturrahim.

Tradisi bantai adat yang dilakukan oleh masyarakat Merangin dalam pelaksanaannya ternyata juga mengalami kendala seperti kesulitan pengadaan ternak. Terkadang saat pelaksanaan tradisi bantai adat, jumlah ternak disetiap desa kurang sehingga terpaksa diatasi dengan membeli kerbau dari daerah lain termasuk pula dari luar Jambi. Selain itu, solusi yang dilakukan oleh masyarakat Merangin adalah meningkatkan produksi ternak di seluruh desa untuk bekal tradisi bantai adat di tahun selanjutnya.

${ }^{36}$ Siti Makhmudah, "Makna Ritual Istighosah Yamisda bagi Masyarakat Islam (Studi Kasus di Makam Syekh Ihsan Bin Muhammad Dahlan Desa Putih Kecamatan Gampengrejo Kabupaten Kediri)", Prosiding Seminar Nasional \& Teтu Ilmiah Jaringan Peneliti IAI Darussalam Blokagung Banyuwangi, 2019, 137. 2018),41.

${ }^{37}$ Acep Zamzam Noor, Islam Santai. (Yogyakarta: IRCiSoD, 


\section{Nilai-Nilai yang Terkandung dalam Tradisi Bantai Adat Merangin}

Menurut penuturan Muhammad Fuad yang merupakan tokoh masyarakat Desa Rantau Panjang, Kec. Tabir Kab. Merangin, tradisi bantai adat memiliki nilai-nilai sosial dan religius yang dapat dijadikan bekal iman selama menunaikan ibadah puasa. Dengan adanya bantai adat, dapat meningkatkan semangat gotong royong, saling menolong warga masyarakat sekitar $^{38}$. Selain itu, terdapat pula nilai-nilai budaya lokal pada tradisi bantai adat tersebut.

\section{Nilai sosial}

Nilai sosial adalah sesuatu yang menjadi ukuran dan penilaian pantas tidaknya suatu sikap yang ditujukan dalam kehidupan bermasyarakat. Nilai ini memperlihatkan sejauh mana hubungan seorang individu dengan individu lainnya terjalin sebagai anggota masyarakat. Nilai sosial sangat nyata dalam aktivitas bermasyarakat. Nilai sosial tersebut dapat berupa nilai gotong royong, ikut terlibat dalam kegiatan musyawarah, kepatuhan, kesetiaan, dan lain sebagainya. Nilai-nilai sosial memiliki fungsi umum dalam masyarakat. Secara garis besar, berdasarkan pendapat ahli bahwa nilai sosial mempunyai tiga fungsi, yaitu sebagai petunjuk arah dan pemersatu, benteng perlindungan, dan pendorong. ${ }^{39}$

Dari fungsi nilai sosial tersebut, dapat dijabarkan maksud dari setiap poinnya sebagai berikut: a) Sebagai faktor pendorong, maksudnya adalah ketika di dalam suatu nilai terdapat hal-hal yang menjadi daya perangsang kuat terhadap setiap manusia yang normal, hal tersebut dapat berupa suatu penghargaan dalam bentuk jabatan, prestasi, dan atas segala hal yang dilakukan oleh seorang individu, (b) Sebagai petunjuk arah dan pemersatu maksudnya, adalah setiap tindakan dan cara berpikir manusia pada umumnya diarahkan

38 Asrori, Loc. Cit.

39 Susianti Aisah, "Nilai-Nilai Sosial yang Terkandung dalam Cerita Rakyat "Ence Sulaiman" pada Masyarakat Tomia", Jurnal Humanika 13, no. 15 (2015). 
oleh nilai-nilai sosial yang berlaku dalam masyarakat yang bersangkutan, (c) Sebagai benteng perlindungan, maksudnya adalah nilai sosial sebagai nilai-nilai ini (proses) dari berbagai kegiatan sosial yang terdapat dalam suatu masyarakat. Masyarakat akan berusaha mempertahankan nilai-nilai ini tersebut karena apabila terjadi gangguan terhadap nilai tersebut maka pola yang selama ini berjalan di masyarakat atau di lingkungannya akan hancur. ${ }^{40}$

Nilai-nilai sosial, khususnya yang berkaitan dengan budaya dibentuk dan dikaryakan oleh masyarakat itu sendiri, nilainilai sosial yang dibentuk selanjutnya dilestarikan dan diyakini sebagai nilai leluhur yang sudah ada sejak lama dan dianggap sebagai warisan leluhurnya terdahulu. Maka tidak bisa disanggah bahwa nilai-nilai sosial menjadi sebuah alat penyatu, atau pemicu solidaritas antara anggota masyarakat satu dengan masyarakat lainnya. ${ }^{41}$

Pada tradisi bantai adat, nilai-nilai sosial yang dapat diperoleh antaralain kerjasama, gotong royong, kebersamaan, solidaritas, silaturahmi, serta kerukunan antar sesama masyarakat. Dalam tradisi adat apapun, termasuk bantai adat, setiap masyarakat memperoleh kesempatan menyerap pesan dan nilai dari tradisi adat tersebut. Dalam situasi tersebut, rasa kerjasama, gotong royong dan lain sebagainya dalam kehidupan masyarakat dapat tumbuh subur sehingga dapat memperkokoh ikatan antar warga. Selain itu, tradisi adat dapat dipakai sebagai kontrol sosial, interaksi, dan komunikasi antar masyarakat.

40 Mirna Nur Alia Abdullah and Richi Rivalidy Setiawan Putra, "Nyangku: Implementasi Nilai-Nilai Sosial Melalui Ritual Upacara Adat Desa Panjalu Ciamis Jawa Barat", Sosio Edukasi (Jurnal Studi Masyarakat dan Pendidikan 1, no. 2 (2018), 2-3. DOI: 10.29408/se.v2i1.991

${ }^{41}$ Rizki Ramadhan, Bunyamin Maftuh and Siti Komariah, "Nilai-Nilai Sosial Budaya Masyarakat Rantau Etnis Minangkabau sebagai Pedagang di Pasar Al-Wathoniyah, Cakung, Jakarta Timur", Sosietas (Jurnal Pendidikan Sosiologi) 6, no. 1 (2016). DOI: https://doi.org/10.17509/sosietas.v6i1.2873 


\section{Nilai religius}

Nilai religius adalah nilai mengenai konsep kehidupan religius atau keagamaan berupa ikatan atau hubungan yang mengatur manusia dengan Tuhannya. Nilai religius juga berhubungan dengan kehidupan dunia tidak jauh berbeda dengan nilai-nilai lainnya seperti kebudayaan dan aspek sosial selain itu nilai religius juga erat hubunganya dengan kehidupan akhirat yang misterius bagi manusia. Kehidupan akhirat inilah yang membedakan dengan nilai-nilai lainnya ${ }^{42}$. Nilai religius ini indikatornya adalah norma yang bersumber dari Al-Qur'an dan hadist ${ }^{43}$. Namun demikian, indikator tersebut dimaksudkan untuk yang beragama Islam karena sebenarnya nilai-nilai religius bukan berarti berdasarkan satu agama saja, akan tetapi berdasarkan nilai agama dan kepercayaan yang diakui di Indonesia.

Nilai religius merupakan bagian dari salah satu klasifikasi nilai di antaranya nilai ibadah, nilai tauhid, kesatuan, perjuangan, keteladanan, dan persaudaraan. Nilai religius bersumber dari agama dan masuk ke dalam jiwa. Agama merupakan keseluruhan perilaku manusia yang terpuji, hal itu dilakukan semata-mata memperoleh ridho Allah SWT. Penanaman nilai religius penting dalam rangka membentuk etos kerja dalam masyarakat yang sesuai tuntunan Allah dan Rasul-Nya. Ruang lingkup atau aspek dari nilai religius secara garis besar terbagi atas tiga bagian, yaitu pertama aspek aqidah atau keimanan, yang kedua aspek keagamaan atau ibadah, dan yang ketiga adalah akhlak. Ketiga aspek tersebut saling berhubungan dan tidak bisa dipisahkan. Keberagamaan tidak hanya soal ritual

${ }^{42}$ Erni Susilawati, "Nilai-Nilai Religius dalam Novel Sandiwara Bumi Karya Taufikurrahman Al-Azizy". Stilistika: Jurnal Bahasa, Sastra, dan Pengajarannya 2, no. 1 (2017), 37-38. https://doi.org/10.33654/sti.v2i1.377

${ }^{43}$ Darul Ilmi, "Pendidikan Karakter Berbasis Nilai-Nilai Kearifan Lokal Melalui Ungkapan Bijak Minangkabau", Islam Realitas: Journal of Islamic \& Social Studies 1, no.1 (2015), 51. http://dx.doi.org/10.30983/islam_ realitas.v1i1.7 
ibadah saja, namun juga dalam aktivitas lainnya. Islam mendorong pemeluknya agar beragama secara menyeluruh. ${ }^{44}$

Terkait dengan nilai religius pada tradisi bantai adat, dapat dilihat dari maksud dilaksanakannya tradisi tersebut. Masyarakat Merangin melakukan penyembelihan hewan ternak sebagai ungkapan rasa syukur dan suka cita menyambut datangnya bulan Ramadhan. Sebagaimana kita ketahui bahwa bulan Ramadhan adalah bulan yang penuh berkah dan orangorang yang bersuka cita menyambut Ramadhan akan diharamkan padanya api neraka. Selain itu berkaitan dengan aspek akhlak, dengan diadakannya bantai adat maka masyarakat setempat dapat memenuhi kebutuhannya terhadap daging selama Ramadhan dengan harga yang lebih murah termasuk juga orang yang tidak mampu. Bantai adat menjadikan masyarakat belajar untuk saling berbagi dan mau bersedekah kepada orang lain dengan cara menjual daging dengan harga murah agar semua orang bisa memperoleh daging tersebut. Tradisi bantai adat ini juga diikuti dengan kegiatan lain seperti makan besamo, beduon dan istighosah yang dalam kegiatannya bertujuan mendekatkan diri dan memohon perlindungan pada Allah SWT terutama selama melaksanakan puasa Ramadhan.

\section{Nilai Budaya Lokal}

Setiap komponen dalam kearifan lokal memiliki makna, isi pesan tentang normal sosial, nilai-nilai budaya dan sebagai wujud kebudayaan yang mengatur sistem sosial dalam menata aktivitas kehidupan sosial masyarakatnya. Nilai-nilai budaya ini merupakan pedoman bagi manusia dalam berperilaku mengenai apa yang hidup dalam alam pikiran sebagai besar

\footnotetext{
${ }^{44}$ Priyanto, Muhammad Agung, "Penanaman Nilai-Nilai Religius melalui Kegiatan Keagamaan pada Jamaah di Masjid Fatimatuzzahra Grendeng Purwokerto”, (Institut Agama Islam Negeri Purwokerto, 2018), 24.
} 
masyarakatnya. Nilai-nilai budaya tersebut berkait dengan cerminan identitas budaya masyarakat. ${ }^{45}$

Nilai-nilai budaya lokal dalam tradisi bantai adat ini memberikan cerminan identitas budaya masyarakat Merangin yang berkaitan dalam hubungannya dengan Tuhan dan sesama manusia. Pada dasarnya nilai-nilai budaya ini juga berhubungan dengan nilai sosial dan nilai religius. Dalam hubungan dengan Tuhan, nilai budaya tradisi bantai adat meliputi syukur dengan dan suka cita dalam menyambut datangnya Ramadhan. Sementara dalam hubungannya dengan manusia, nilai budaya tradisi bantai adat meliputi budaya gotong royong, tolong menolong, serta persaudaraan selama pelaksanaan bantai adat yang nantinya akan tetap turun temurun dirasakan oleh anak cucu kita kelak.

\section{PENUTUP}

Tradisi bantai adat Merangin Jambi bermula dari kisah Datuk Putih dan Datuk Mangkuto Rajo yang menemukan tempat yang disebut Renah Sungai Kunyit. Kedua Datuk tersebut membuat tempat menyabung ayam yang menyebabkan banyak pendatang ke tempat tersebut hingga harus dibentuk undangundang karena terdapat keberagaman adat istiadat. Inti undangundang tersebut adalah wajah nan tigo dan pembetulan nan duo yang merupakan kombinasi undang-undang dari Minangkabau dan Jambi. Saat peresmian undang-undang tersebut, disembelih puluhan ekor kerbau dan menjadi tradisi yang terus berlangsung hingga kini.

Bantai adat dilaksanakan setiap menyambut bulan Ramadhan oleh masyarakat hampir diseluruh wilayah Kabupaten Merangin. Bantai adat dilaksanakan tiga atau lima hari sebelum masuknya bulan Ramadhan dengan tujuan melestarikan tradisi dan memenuhi kebutuhan daging masyarakat yang dipatok dengan harga yang relatif murah dibandingkan harga pasar agar semua kalangan dapat menikmatinya. Biasanya hewan yang

${ }^{45}$ Esti Verulitasari and Agus Cahyono, "Nilai Budaya dalam Pertunjukan Rapai Geleng Mencerminkan Identitas Budaya Aceh", Catharsis: Journal of Arts Education 5, no. 1 (2016), 42. 
disembelih pada tradisi ini berasal dari keluarga yang berkelompok atau perorangan atau juga pedagang biasa. Proses pembantaian tersebut dilakukan di balai atau tanah lapang.

Terdapat nilai-nilai yang terkandung dalam tradisi bantai adat antara lain nilai sosial, nilai religius dan nilai budaya. Nilai sosial yang tampak pada tradisi bantai adat adalah kerjasama, gotong royong, kebersamaan, solidaritas, silaturhami dan kerukunan antar masyarakat. Sedangkan nilai religius yang tampak pada tradisi ini adalah penyembelihan hewan ternak sebagai ungkapan rasa syukur dan suka cita menyambut bulan Ramadhan. Selain itu, setelah tradisi bantai adat juga diikuti kegiatan keagamaan lain seperti beduon dan istighosah. Untuk nilai budaya lokal, berkaitan dengan identitas yang muncul karena tradisi lokal tersebut. Nilai budaya berkaitan erat dengan nilai sosial dan nilai religius dalam hubungannya dengan manusia dan Tuhan seperti rasa syukur dan suka cita menyambut Ramadhan dan munculnya budaya gotong royong, tolong menolong serta persaudaraan.

\section{DAFTAR PUSTAKA}

\section{Buku}

Amru, Abu Maryam Kautsar. Memantaskan Diri Menyambut Ramadhan. Ciputat: Kautsar Amru Publishing, 2018.

Burhanudin, Yusuf. Misteri Bulan Ramadhan. Jakarta: Qultummedia, 2007.

Jauzi, Ibnu. Diterjemahkan oleh Iman Firdaus. Suluh Penyucian Jiwa. Jakarta: Qisthi Press, 2016.

Muhammad, Naser. Menggapai Mulia Ramadhan dengan Ilmu. Lampung: Perahu Litera, 2018.

Nasution, Fitri Haryani. 70 Tradisi Unik Suku Bangsa di Indonesia. Jakarta: Bhuana Ilmu Populer, 2019.

Noor, Acep Zamzam. Islam Santai. Yogyakarta: IRCiSoD, 2018. 


\section{Jurnal Ilmiah}

Abdullah, Mirna Nur Alia and Putra, Richi Rivalidy Setiawan. "Nyangku: Implementasi Nilai-Nilai Sosial Melalui Ritual Upacara Adat Desa Panjalu Ciamis Jawa Barat". Sosio Edukasi (Jurnal Studi Masyarakat dan Pendidikan 1, no. 2 (2018): 1-7. DOI: 10.29408/se.v2i1.991.

Aisah, Susianti. "Nilai-Nilai Sosial yang Terkandung dalam Cerita Rakyat "Ence Sulaiman" pada Masyarakat Tomia". Jurnal Humanika 13, no.15 (2015).

Alhusni. "Tradisi Bebantai Menyambut Bulan Ramadan dalam Masyarakat Merangin Jambi”. Kontekstualita 29, no. 1 (2014): 41-51.

Bakry, Umar Suryadi. "Pemanfaatan Metode Etnografi dan Netnografi Dalam Penelitian Hubungan Internasional". Global \& Strategis 11, no. 1 (2017): 15-26. http://dx.doi.org/10.20473/ jgs.11. $\underline{1.2017 .15-26}$

Habriyanto., Nasution, Muhammad Yasir and Harahap, Muhammad Yusuf. "Analisis Pola Konsumsi Masyarakat Kota Jambi pada Bulan Ramadhan Menggunakan Pendekatan Smart Pls 3.0". Jurnal Ilmiah Universitas Batanghari 19, no. 1 (2019): 18-126. DOI: 10.33087/Jiubj.V19i1.573

Ilmi, Darul. "Pendidikan Karakter Berbasis Nilai-Nilai Kearifan Lokal Melalui Ungkapan Bijak Minangkabau”. Islam Realitas: Journal of Islamic \& Social Studies 1, no.1 (2015): 45-54. http:// dx.doi.org/10.30983/islam realitas.v1i1.7

Kusuma, Ari Yuda and Aman. "Budaya Keagamaan Arab Melayu Seberang Kota Jambi". Jurnal Lektur Keagamaan 19, no. 1 (2021): 239-268. DOI: 10.31291/jlk.v19i1.899

Neonnub, Fransiska Idaroyani and Habsari, Novi Triana. "Belis: Tradisi Perkawinan Masyarakat Insana Kabupaten Timor Tengah Utara (Kajian Historis Dan Budaya Tahun 2000-2017)". Jurnal Agastya 08, no. 01 (2018): 107-126. http://doi.org/ 10.25273/ajsp.v8i01.2035 
Pintenate, Amalia and Bukhari. "Pacuan Kuda dalam Kajian Sosiologi (Suatu Penelitian di Kabupaten Bener Meriah)". Jurnal Ilmiah Mahasiswa FISIP Unsyiah 2, no. 2 (2017): 907 - 926.

Priyatna, Muhammad. "Pendidikan Karakter Berbasis Kearifan Lokal". Jurnal Edukasi Islami Jurnal Pendidikan Islam 5, no. 10 (2016): 1311-1336. http://dx.doi.org/10.30868/ei.v5i10.6

Ramadhan, Rizki., Maftuh, Bunyamin and Komariah, Siti. "Nilai-Nilai Sosial Budaya Masyarakat Rantau Etnis Minangkabau sebagai Pedagang di Pasar Al-Wathoniyah, Cakung, Jakarta Timur". Sosietas (Jurnal Pendidikan Sosiologi) 6, no. 1 (2016). DOI: https://doi.org/10.17509/sosietas.v6i1.2873

Ramadani, Suci., Risnawati and Yarlis. "Tari Dendang Rumah Tuo pada Masyarakat Rantau Panjang Kecamatan Tabir Kab. Merangin Prov. Jambi”. Jurnal Laga-Laga 5, no. 2 (2019): 280289.

Siddiq, Mohammad and Salama, Hartini. "Etnografi Sebagai Teori Dan Metode". Kordinat Xviii, no. 1 (2019): 23-48. DOI: 10.15408/kordinat.v18i1.11471

Susilawati, Erni. "Nilai-Nilai Religius dalam Novel Sandiwara Bumi Karya Taufikurrahman Al-Azizy". Stilistika: Jurnal Bahasa, Sastra, dan Pengajarannya 2, no. 1 (2017): 35-53. https:// doi.org/10.33654/sti.v2i1.377

Verulitasari, Esti and Cahyono, Agus. "Nilai Budaya dalam Pertunjukan Rapai Geleng Mencerminkan Identitas Budaya Aceh". Catharsis: Journal of Arts Education 5, no. 1 (2016): 41-47

Windiani and Rahmawati, Farida Nurul. "Menggunakan Metode Etnografi dalam Penelitian Sosial". Dimensi 9, no. 2 (2016): 8792.

\section{Prosiding}

Fatriani, Riri Maria and Bafadhal, Faizah. "Involvement Of Malay Customary Institution In Organizing Development At Tabir SubDistrict Merangin Regency". Proceedings of The 1st Progress in Social Science, Humanities and Education Research Symposium (Psshers 2019), 2019: 636-640. 
Makhmudah, Siti. "Makna Ritual Istighosah Yamisda bagi Masyarakat Islam (Studi Kasus di Makam Syekh Ihsan Bin Muhammad Dahlan Desa Putih Kecamatan Gampengrejo Kabupaten Kediri)". Prosiding Seminar Nasional \& Temu Ilmiah Jaringan Peneliti IAI Darussalam Blokagung Banyuwangi, 2019: 128149.

\section{Laporan Penelitian}

Hartati. "Pembacaan Surat-Surat Pilihan Pada Tradisi Selamatan Pindah Rumah di Desa Tanjung Mudo Kecamatan Pangkalan Jambu Kabupaten Merangin Jambi (Studi Living Qur'an)". Universitas Islam Negeri Sulthan Thaha Saifuddin Jambi, 2021.

Madri. "Tradisi Adat Makan Jantung Kerbau Di Marga Tanah Renah Desa Muara Panco Kecamatan Renah Pembarap Kabupaten Merangin Provinsi Jambi (Studi Fenomenologi Edmund Husserl)". Universitas Islam Negeri Sulthan Thaha Saifuddin Jambi, 2021.

Pigria, Samratul. "Peran Da'i dalam Menyikapi Tradisi Naik Alang Rumah (Studi di Kelurahan Pamenang Kecamatan Pamenang Kabupaten Merangin)". Universitas Islam Negeri Sulthan Thaha Saifuddin Jambi, 2019.

Priyanto, Muhammad Agung. "Penanaman Nilai-Nilai Religius melalui Kegiatan Keagamaan pada Jamaah di Masjid Fatimatuzzahra Grendeng Purwokerto". Institut Agama Islam Negeri Purwokerto, 2018.

Roni, Ahmad. "Makna Filosofis Tradisi Pampeh Luko (Studi di Kecamatan Muara Siau Kabupaten Merangin Provinsi Jambi)". Universitas Islam Negeri Sulthan Thaha Saifuddin Jambi, 2021.

Saputra, Migoni. "Tradisi Adat Mukodumah di Desa Renah Alai Kecamatan Jangkat Kabupaten Merangin Provinsi Jambi". Universitas Islam Negeri Sulthan Thaha Saifuddin Jambi, 2021.

Saulatiyah. "Kebijakan Pemerintah Dalam Pelestarian Rumah Tuo Di Kelurahan Kampung Baruh Kecamatan Tabir Kabupaten Merangin Provinsi Jambi". Universitas Islam Negeri Sulthan Thaha Saifuddin Jambi, 2021. 


\section{Website}

Asrori. "Warga Merangin Punya Tradisi Bantai Adat". Info Jambi.com, 2017. https://infojambi.com/9472-2/

Redaksi. "Gambaran Umum Kabupaten Merangin". Meranginkab. Go.Id, 2017. https://Meranginkab.Go.Id/ Profile/ GambaranUmum

Redaksi. "Adat Mamantai Kerbau Rantau Panjang, Habiskan Rp 1,4 Miliar". Jambiberita.com, 2021. https://jamberita.com/read/ 2021/04/10/5966942/ adat-mamantai-kerbau-rantau-panjanghabiskan-rp-14-miliar/

Santoso, Bangun. "Tradisi Bantai Kerbau Sambut Ramadan di Merangin Jambi”. Liputan 6.com, 2017. https://www. liputan6. com/ramadan/read/2961895/tradisi-bantai-kerbau-sambut ramadan-di-merangin-jambi

Saragih, Radesman. "Tradisi Bantai Adat, Perekat Kebersamaan Memasuki Bulan Ramadan”. Beritasatu.com, 2018. https:// www.beritasatu.com/ramadan/493250/tradisi-bantai-adatperekat-kebersamaan-memasuki-bulan-ramadan

Suwandi. "Mengenal Sejarah Bebantai, Tradisi Sambut Ramadhan di Merangin".Kompas Online, 2021. https://regional.kompas. com/ $\mathrm{read} / 2021 / 04 / 13 / 18434$ 5578/mengenal-sejarah-bebantai-tradisisambut-ramadhan-di-merangin?page=all. 


\section{Lampiran}

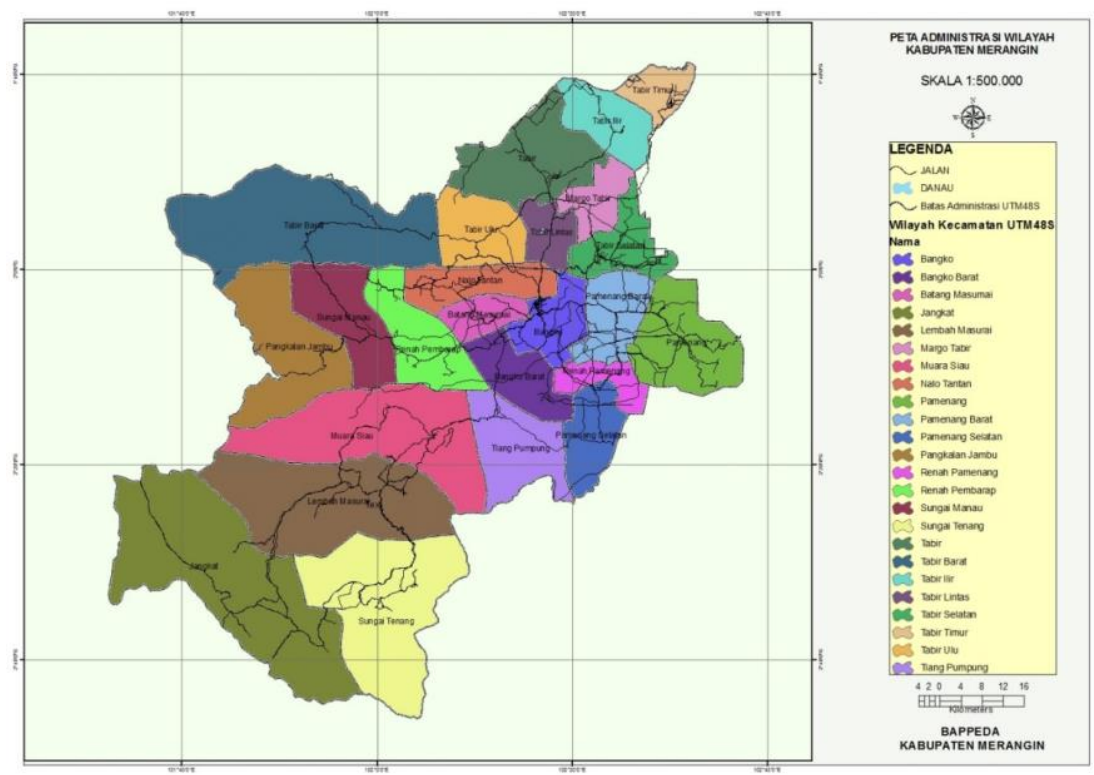

Sumber: meranginkab.go.id, 2017

Gambar 3.

Peta Administrasi Kabupaten Merangin. 